\section{Einfrieren der Proben}

W. G. Guder

München, Deutschland

Synonym(e) Gekühlte Lagerung; Tiefgefrorene Proben

Englischer Begriff freezing of samples

Definition Kühlung von Proben unter $0{ }^{\circ} \mathrm{C}$, sodass flüssige Proben in festen Zustand übergehen.

Schockfrieren: Einfrieren durch flüssigen Stickstoff oder andere Kühlmittel, die ein Einfrieren innerhalb einer Sekunde ermöglichen.

Tieffrieren: Einfrieren auf Temperaturen $\leq-20{ }^{\circ} \mathrm{C}$, d. h. unter die Temperatur üblicher Gefrierfächer von Kühlschränken. Dabei werden Temperaturen von $-20,<-20$ und $-70{ }^{\circ} \mathrm{C}$ unterschieden.

Beschreibung Immer, wenn die Aufbewahrungszeit einer - Probe bis zur Analyse die Stabilität eines Analyten ( $\triangleright$ Analyt) bei Raum- oder Kühlschranktemperatur nicht sicher gewährleistet, wird Einfrieren auf mindestens $-20{ }^{\circ} \mathrm{C}$ empfohlen. Dies basiert auf der Annahme, dass metabolische Veränderungen, bakterielle Verunreinigung und Überlagerung damit verhindert werden können. Auf der anderen Seite sind durch den Einfriervorgang bedingte physikalischchemische Prozesse zu vermeiden, die eine Veränderung des Analyten in der Matrix verhindern. So werden Zellen durch Einfrieren zerstört, sollten also vorher von der analytischen Probe Serum oder Plasma abgetrennt werden. Aus Serum und/oder Urin können manche Substanzen durch Einfrieren kristallisieren oder unlösliche Komplexe bilden, sodass sie nach Wiederauftauen der Probe nicht mehr in Lösung gehen.

Aus diesen Gründen wurden für jeden Analyten getrennt Empfehlungen ausgesprochen, ab welcher Zeit und wie lange Proben einzufrieren sind. Diese Empfehlungen sind den Einsendern eines Labors zur Verfügung zu stellen, wenn instabile Analyte über längere Zeit transportiert oder aufbewahrt werden sollen.

\section{Literatur}

Guder WG, da Fonseca-Wollheim F, Heil W, Schmitt Y, Töpfer G, Wisser H, Zawta B (2012) Die Qualität diagnostischer Proben, 7. Aufl. BD, Heidelberg 